\title{
Exploring the Impact of Talent Management on the Organizational Effectiveness in the Egyptian Hospitality Industry
}

\author{
Reda M. A. Gadelrab \\ Faculty of Tourism and Hotel Management, Helwan University
}

\begin{abstract}
:
The main purpose of this study is to explore Talent Management within hospitality industry through focusing on how Talent Management affects the Organizational Effectiveness. The survey of this study is conducted on 71 entry, middle and senior levels of the human resources department to obtain their perspectives related to Talent Management in ten five star hotels and six four star hotels. The obtained data are analyzed through the SPSS version 22. The main finding of this study is that Talent Management integrates with human resources procedures and has a strong significant positive impact on Organizational Effectiveness.
\end{abstract}

Keywords: Hospitality Industry; Human Resources; Talent Management; Talents;

Organizational Effectiveness; Egypt.

\section{Introduction:}

The human resources represent one of the major costs and also one of the main pillars of contemporary organizations, since the degree of their success and survival is determined by the quality, attitudes and behaviors of their people in the work place (Alleyne et al., 2006; Davidson et al., 2010). Therefore, human resources is a critical issue in delivering services and products in the hospitality industry (Gill, 2008; Robinson et al., 2010).

The Egyptian hotel sector has shown a strong growth in the recent years (Nassar, 2012). It should be noticed that the hotels are considered the largest employer in tourism sector (Collins, 2007) that needs effective human resources practices to achieve competitive advantage (Raub et al., 2006; Chalkiti and Sigala, 2010). Thus, managing people in the hotel industry is a big dilemma (Alleyne et al., 2006), as more emphasis has been placed on delivering consistent quality products and services (Gadelrab, 2010).

\section{Literature Review:}

According to Baum (2008) there is a lack of research on Talent Management and its development within the hospitality industry. He referred Talent to ensure that the hospitality sector is able to recruit, retain, support and develop personnel of the highest quality consistent with the diversity of work and employment situations that exist within the sector.

Talent Management:

There is no clear and single description for talent management (Lewis and Heckman, 2006). However, it can be considered as people who have specific qualifications or knowledge distinguishing them from others and restricting them to be replaced within the organization. It is more than Human Resources Management (D'Annunzio-Green, 2008). It is a holistic approach to recruiting, retaining and developing talent within the organization for its sustainable benefit (Iles et al., 2010). The term Talent Management was first introduced by McKinsey and Company in 1997, it is a professional term that has recently been common in the early 2000s (Wikipedia, 2013). It means the process of developing and fostering new workers through interviewing, hiring, orienting and successfully integrating new hires into an organization's culture, and thereafter, developing and keeping current workers and attracting highly skilled workers to work for an organization. Again it is a strategy used by organizations to consider how they identify, attract, retain and develop employees through the organization (Deery, 2008; Scott and Revis, 2008). In summary, it is about aligning the right personnel with the right jobs at the right time (Baum, 2008), since it is a holistic approach to the Human Resources Management (Watson, 2011). Therefore, maintaining stable and well-qualified employees represents a key asset of talent management which is considered a big challenge to hospitality operations (Martin et al., 2006; Maxwell and MacLean, 2008). 
Identification of Talents:

Williams (2000) 35; cited in Iles et al. (2010) stated that talented people are those who do the following: "Regularly demonstrate exceptional ability and achievement either over a range of activities and situations, or within a specialized and narrow field of expertise; consistently indicate high competence in areas of activity that strongly suggest transferable, comparable ability in situations where they have yet to be tested and proved to be highly effective". In summary, talents are the most effective managers, leaders or people at all levels who can help a company fulfill its aspirations and drive its performance (Iles et al., 2010).

Attraction of Talents:

Maxwell and MacLean (2008) ascertained that training and work life balance are critical issues to attract new talents in the industry. According to Beardwell (2010) attracting talents is targeted at the external work market. It includes the use of recruitment and selection techniques to identify skills required, then attracting the most qualified people to meet an organization's goals (Armstrong, 2012).

Retention of Talents:

In terms of employee retention, Deery (2008) stated particular issues that should be taken into account to ensure employee retention, e.g. appropriate recruitment, training and balance between work and life. Therefore, survival and success of the organization is relying substantially on the employee retention (Vural et al., 2012). Davies and Davies (2010) ascertained that money does not retain talented people, since they advocated spending the money on talent rather than giving it to them.

Development of Talents:

Energizing and involving talents will create a positive work environment which produces the most satisfied and loyal customers (Tews and Tracey, 2009; Garlick, 2010). This is through adopting transformational leadership which means that hotel employees are motivated and encouraged to use their own judgment and intelligence to solve problems while performing their jobs by transferring missions to them, and expressing appreciation for good work (Brownell, 2010; Gill et al., 2011). Therefore customer satisfaction is regarded by the employee job satisfaction (Gu and Siu, 2009; Gallardo et al., 2010; Pelit et al., 2011). Thus, effective development of talents should be used to retain talented personnel, since selecting the most talented people is not enough for the organizational success (Vural et al., 2012).

Organizational Effectiveness:

Talent Management is considered as an organizational approach ensuring the availability of talents (Baum, 2008) and talents can be treated on an organizational manner (Vural et al., 2012). Organizational effectiveness is the individual's belief in and desire to achieving organization's goal and value (Vural et al., 2012). It is recognized as the performance outputs that can be measured more easily than input factors (Meyers et al., 2013). Effective Talent Management can create a long-term organizational effectiveness through getting the right people in the right place at the right time (Ashton and Morton, 2005). Clrake and Winkler (2006) emphasized the use of Talent Management concept to enhance organizational effectiveness and the support of industry branding through tracking the performance and progress of those identified as talents. According to Maxwell and MacLean (2008) the hospitality sector can benefit from using a talent management strategy as a successful way of organizational effectiveness in the industry than others, thereby can achieve the best outcome from talents' performance at work (Vural et al., 2012).

\section{Methodology:}

The population of the research included five and four star hotels in Greater Cairo. Human Resources Managers (seniors and middle) were chosen as a sample. Titles of seniors varied, i.e. Executive Human Resources; Director of Human Resources; Human Resources Manager; Recruitment Manager; Training Manager; Personnel Manager. They are assisted by middle managers who participated in the current study. A convenience sampling method was preferred as a sampling method for the research to enable easier reach to data collection.

Considering the five star hotels, the total number of population is 32 hotels (Egyptian Hotel Association, 2012). Ten out of 32 hotels (31.3\%) agreed to participate in the study. The sample consisted of 23 Senior Managers and 32 Middle Managers in charge of Human Resources. As for the four star hotels, the total number was 16 hotels, six out of them (37.5\%) agreed to cooperate through seven Senior Managers and nine 


\section{Exploring the Impact of Talent Management on the Organizational Effectiveness in the Egyptian Hospitality Industry}

Middle Managers responsible for Human Resources. Thus, the total numbers of seniors and middle managers for both hotel categories were 30 and 41 respectively.

A questionnaire using five rating Likert scale was used to investigate human resources managers' perspectives regarding Talent Management and its impact on the Organizational Effectiveness. The rating scale was ranged from 1 to 5 , where one for "strongly disagree" and five referred to "strongly agree". The research instrument was pre-tested and reworded after an interview with some of the Human Resources Managers to ensure the instrument validation. The questionnaire consisted of five key sections with 60 statements. Four sections are for Talent Management and one section is for the Organizational Effectiveness:

1- Identification of Talents includes four statements;

2- Attraction of Talents includes 15 statements;

3- Retention of Talents includes 15 statements;

4- Development of Talents includes 16 statements;

5- Organizational Effectiveness includes ten statements.

Appropriate statistical analyses namely: Cronbach's Alpha Reliability test to ensure the reliability of the five sections of the questionnaire distributed; Frequencies to illustrate descriptive analysis of managers scores in terms of their consent to questionnaire statements; Spearman Rank Correlations to investigate whether there are relationship among the four different sections of Talent Management and Organizational Effectiveness section; Non Parametric Tests using Mann Whitney U Test to identify variances among hotel categories and managers level in terms of their scores.

\section{Findings and Discussion:}

Reliability of the questionnaire:

Table 1: Reliability Statistics for all five sections of the questionnaire

\begin{tabular}{|l|l|l|}
\hline Questionnaire category & $\begin{array}{l}\text { Cronbach's } \\
\text { Alpha }\end{array}$ & N of Items \\
\hline Identify Talents & .873 & 4 \\
\hline Attract Talents & .963 & 15 \\
\hline Retain Talents & .958 & 15 \\
\hline Develop Talents & .962 & 16 \\
\hline $\begin{array}{l}\text { Organizational } \\
\text { Effectiveness }\end{array}$ & .949 & 10 \\
\hline \multicolumn{2}{|l|}{ Total of Questionnaire Statements } & 60 \\
\hline
\end{tabular}

Considered reliable if Cronbach's Alpha is more than 0.70

Cronbachs' Alpha reliability measures for all five sections of the questionnaire are $.873 ; .963 ; .958 ; .962$; .949 respectively as shown in. This indicates that the overall 60 statements of the questionnaire and the scale are reliable to be measured in the current study (Table1).

Descriptive Analysis for the whole Questionnaire Items:

The 60 items were illustrated by their means, modes, standard deviation, variance, range, minimum score, maximum score, and sum of the scores. All these statistics are shown in Tables $2-6$.

Considering Identification of Talents, the results in Table 2 show that 3 out of 4 statements were found important as their modes equal 4 which means that most of the respondents are agreeing to statements 1,2 , and 4. These statements are: "Skills, abilities, experiences and qualifications needed for selection are identified according to the strategy, goals and culture of the organization."; "There are clear and specific 
standards for measuring talents in the organization."; "There is a comprehensive database of talents in the organization."

Regarding Attraction of Talents, the findings in Table 3 indicate that 14 out of 15 statements in this section were found significant as their modes equal 4. This indicates that most of the respondents agreed to all statements of the second section. These statements are from $1-15$ except statement 12 "The brand of the organization represents something that everyone wants to be enrolled in."

In terms of Retention of Talents, it was found that 11 out of 15 statements were significant as their modes equal 4 (Table 4). This states that most of the respondents agree to all statements of the third section except statements 1"Aligning employees with the mission and vision of the organization."; 3 "Locating qualified professionals needed in the right positions."; 8 "A written career development plan for talents is in place within the organization."; and 14 "Your organization currently allocated a formal budget in place for employees' retention."

As for "Development of Talents", the results in Table 5 reveal that 13 out of 16 statements were important as their modes equal 4. This means that most of the respondents agreed to all 16 statements in the fourth section except statements 4 "Creating an environment where employees' ideas are listened to and valued."; 7 "Conducting formal performance appraisals on a regular basis (quarterly; biannually; annually)."; 16 "Preparing current employees to improve performance to surpass expectations."

With regard to the Organizational Effectiveness, nine out of ten statements were significant as their modes equal 4 (Table 6). This leads to that most of the respondents agreed to the whole section except statement 3 "The organization seeks to achieve consumer satisfaction through providing quality products at reasonable prices."

Relationships between Talent Management and Organizational Effectiveness:

The results in Tables 7; 8; 9; 10 illustrates correlations among Talent Management four sections and the Organizational Effectiveness section. All statements of all five sections were coded and numbered according to its position in the questionnaire; "Identification of Talents" Statements were coded as ITS1 to ITS4, "Attraction of Talents" Statements were coded as ATS1 to ATS15, "Retention of Talents" Statements were coded RTS1 to RTS15, "Development of Talents" Statements were coded as DTS1 to DTS16 and "Organizational Effectiveness" Statements were coded as OES1 to OES10. 
Exploring the Impact of Talent Management on the Organizational Effectiveness in the Egyptian Hospitality Industry

Table 2: A Descriptive Analysis of "Identification of Talents" Statements

\begin{tabular}{|c|c|c|c|c|c|c|c|c|c|c|}
\hline \multirow[b]{2}{*}{ Item } & \multicolumn{2}{|c|}{$\mathbf{N}$} & \multirow[b]{2}{*}{ Mean } & \multirow{2}{*}{$\begin{array}{c}\text { Mod } \\
\text { e }\end{array}$} & \multirow{2}{*}{$\begin{array}{c}\text { Std. } \\
\text { Deviatio } \\
n\end{array}$} & \multirow{2}{*}{$\begin{array}{c}\text { Varianc } \\
\text { e }\end{array}$} & \multirow{2}{*}{$\begin{array}{c}\text { Rang } \\
\text { e }\end{array}$} & \multirow{2}{*}{$\underset{\mathbf{m}}{\operatorname{Minimu}}$} & \multirow{2}{*}{$\underset{\mathbf{m}}{\text { Maximu }}$} & \multirow{2}{*}{$\begin{array}{c}\text { Su } \\
\text { m }\end{array}$} \\
\hline & $\begin{array}{c}\text { Vali } \\
\text { d }\end{array}$ & $\underset{\mathbf{g}}{\text { Missin }}$ & & & & & & & & \\
\hline $\begin{array}{r}\text { 1-Skills, } \\
\text { abilities, } \\
\text { experiences } \\
\text { and } \\
\text { qualifications } \\
\text { needed for } \\
\text { selection are } \\
\text { identified } \\
\text { according to } \\
\text { strategy, } \\
\text { goals and } \\
\text { culture of the } \\
\text { organization. }\end{array}$ & 71 & 0 & $\begin{array}{c}3.732 \\
4\end{array}$ & 4 & 0.75513 & 0.57 & 3 & 2 & 5 & 265 \\
\hline $\begin{array}{r}\text { 2-There are } \\
\text { clear and } \\
\text { specific } \\
\text { standards for } \\
\text { measuring } \\
\text { talents in the } \\
\text { organization. }\end{array}$ & 71 & 0 & $\begin{array}{c}3.098 \\
6\end{array}$ & 4 & 0.84777 & 0.719 & 2 & 2 & 4 & 220 \\
\hline $\begin{array}{r}\text { 3-There are } \\
\text { objective } \\
\text { criteria for } \\
\text { evaluating } \\
\text { employees' } \\
\text { performance } \\
\text { inside the } \\
\text { organization. }\end{array}$ & 71 & 0 & $\begin{array}{c}2.985 \\
9\end{array}$ & 3 & 0.90227 & 0.814 & 4 & 1 & 5 & 212 \\
\hline $\begin{array}{r}\text { 4-There is a } \\
\text { comprehensi } \\
\text { ve database } \\
\text { of talents in } \\
\text { the } \\
\text { organization. }\end{array}$ & 71 & 0 & $\begin{array}{c}2.943 \\
7\end{array}$ & 4 & 1.24082 & 1.54 & 4 & 1 & 5 & 209 \\
\hline
\end{tabular}


Table 3: A Descriptive Analysis of "Attraction of Talents" Statements

\begin{tabular}{|c|c|c|c|c|c|c|c|c|c|}
\hline \multirow{2}{*}{ Item } & \multicolumn{2}{|c|}{$\mathbf{N}$} & \multirow{2}{*}{ Mean } & \multirow{2}{*}{ Mode } & \multirow{2}{*}{$\begin{array}{c}\text { Std. } \\
\text { Deviation }\end{array}$} & \multirow{2}{*}{ Range } & \multirow{2}{*}{ Minimum } & \multirow{2}{*}{ Maximum } & \multirow{2}{*}{ Sum } \\
\hline & Valid & Missing & & & & & & & \\
\hline $\begin{array}{l}\text { 1. There are specific and clear instructions to attract } \\
\text { talents. }\end{array}$ & 71 & 0 & 3.2676 & 4 & 1.10786 & 4 & 1 & 5 & 232 \\
\hline $\begin{array}{l}\text { 2. Attracting talents represents a priority issue in the } \\
\text { organization. }\end{array}$ & 71 & 0 & 2.9718 & 4 & 1.13354 & 4 & 1 & 5 & 211 \\
\hline $\begin{array}{l}\text { 3. Your organization has a staff member whose } \\
\text { position is exclusively responsible for overseeing } \\
\text { talent employees inside and outside the } \\
\text { organization. }\end{array}$ & 71 & 0 & 3.0704 & 4 & 1.01874 & 4 & 1 & 5 & 218 \\
\hline $\begin{array}{l}\text { 4. Creating a culture that makes individuals want to } \\
\text { join the organization. }\end{array}$ & 71 & 0 & 3.0704 & 4 & 1.01874 & 4 & 1 & 5 & 218 \\
\hline $\begin{array}{l}\text { 5. Identifying gaps between current employees and } \\
\text { new hires at competency levels. }\end{array}$ & 71 & 0 & 3.1408 & 4 & 0.97535 & 4 & 1 & 5 & 223 \\
\hline $\begin{array}{l}\text { 6. Identifying vacancies that will be created as the } \\
\text { company advances and expands. }\end{array}$ & 71 & 0 & 2.9859 & 4 & 1.15255 & 4 & 1 & 5 & 212 \\
\hline $\begin{array}{l}\text { 7. Assessing candidates' skills earlier in the hiring } \\
\text { process. }\end{array}$ & 71 & 0 & 3.169 & 4 & 1.15864 & 4 & 1 & 5 & 225 \\
\hline $\begin{array}{l}\text { 8. Using a formal approach to identify why } \\
\text { employees join the organization. }\end{array}$ & 71 & 0 & 3.0986 & 4 & 1.16073 & 4 & 1 & 5 & 220 \\
\hline $\begin{array}{l}\text { 9. Proactively attempting to recruit employees from } \\
\text { competitors. }\end{array}$ & 71 & 0 & 3.6338 & 4 & 0.97452 & 4 & 1 & 5 & 258 \\
\hline $\begin{array}{l}\text { 10. Your organization currently allocated a formal } \\
\text { budget in place for recruiting individuals. }\end{array}$ & 71 & 0 & 3.3099 & 4 & 0.9349 & 3 & 2 & 5 & 235 \\
\hline $\begin{array}{l}\text { 11. It is expected that budget for recruiting individuals } \\
\text { will change over the next three years. }\end{array}$ & 71 & 0 & 3.0282 & 3 & 1.15847 & 4 & 1 & 5 & 215 \\
\hline $\begin{array}{l}\text { 12. The brand of the organization represents } \\
\text { something that everyone wants to be enrolled in. }\end{array}$ & 71 & 0 & 3.0563 & 4 & 0.96935 & 4 & 1 & 5 & 217 \\
\hline $\begin{array}{l}\text { 13. All managers have knowledge about the policies of } \\
\text { recruiting new employees. }\end{array}$ & 71 & 0 & 3.1831 & 4 & 1.09948 & 4 & 1 & 5 & 226 \\
\hline $\begin{array}{l}\text { 14. The direct manager of the vacant job attends the } \\
\text { selection of the candidates to fill the vacancy. }\end{array}$ & 71 & 0 & 3.0845 & 4 & 1.25067 & 4 & 1 & 5 & 219 \\
\hline $\begin{array}{l}\text { 15. The senior management concerned with attracting } \\
\text { talents from inside or outside the organization. }\end{array}$ & 71 & 0 & 3.2817 & 4 & 1.1362 & 4 & 1 & 5 & 233 \\
\hline
\end{tabular}


Exploring the Impact of Talent Management on the Organizational Effectiveness in the Egyptian Hospitality Industry

Table 4: A Descriptive Analysis of "Retention of Talents" Statements

\begin{tabular}{|c|c|c|c|c|c|c|c|c|c|}
\hline \multirow{2}{*}{ Item } & \multicolumn{2}{|c|}{$\mathbf{N}$} & \multirow{2}{*}{ Mean } & \multirow{2}{*}{ Mode } & \multirow{2}{*}{$\begin{array}{c}\text { Std. } \\
\text { Deviation }\end{array}$} & \multirow{2}{*}{ Range } & \multirow{2}{*}{ Minimum } & \multirow{2}{*}{ Maximum } & \multirow{2}{*}{ Sum } \\
\hline & Valid & Missing & & & & & & & \\
\hline $\begin{array}{l}\text { 1. Aligning employees with the mission and } \\
\text { vision of the organization. }\end{array}$ & 71 & 0 & 3.3944 & 3 & 0.99253 & 4 & 1 & 5 & 241 \\
\hline $\begin{array}{l}\text { 2. Creating a culture that makes employees want } \\
\text { to stay with the organization. }\end{array}$ & 71 & 0 & 3.1831 & 4 & 1.09948 & 4 & 1 & 5 & 226 \\
\hline $\begin{array}{l}\text { 3. Locating qualified professionals needed in the } \\
\text { right positions. }\end{array}$ & 71 & 0 & 3.1408 & 3 & 0.85014 & 4 & 1 & 5 & 223 \\
\hline 4. Rewarding top-performing employees. & 71 & 0 & 3.1408 & 4 & 1.12499 & 4 & 1 & 5 & 223 \\
\hline $\begin{array}{l}\text { 5. Creating an environment where employees are } \\
\text { excited to come to work each day. }\end{array}$ & 71 & 0 & 3.1127 & 4 & 1.14079 & 4 & 1 & 5 & 221 \\
\hline 6. The organization aims to retain talents. & 71 & 0 & 3.6197 & 4 & 0.86794 & 3 & 2 & 5 & 257 \\
\hline $\begin{array}{l}\text { 7. Creating a culture where employees } \\
\text { passionately believe in what they are doing. }\end{array}$ & 71 & 0 & 3.2254 & 4 & 0.92886 & 4 & 1 & 5 & 229 \\
\hline $\begin{array}{l}\text { 8. A written career development plan for talents is } \\
\text { in place within the organization. }\end{array}$ & 71 & 0 & 3.0845 & 3 & 0.82369 & 4 & 1 & 5 & 219 \\
\hline $\begin{array}{l}\text { 9. Providing current employees with salary } \\
\text { adjustments as they master significant skills } \\
\text { required for the job. }\end{array}$ & 71 & 0 & 3.1127 & 4 & 1.07636 & 4 & 1 & 5 & 221 \\
\hline 10. Conducting exit interviews. & 71 & 0 & 3.2535 & 4 & 1.28417 & 4 & 1 & 5 & 231 \\
\hline $\begin{array}{l}\text { 11. Using a formal approach to identify why } \\
\text { employees leave the organization. }\end{array}$ & 71 & 0 & 3.0704 & 4 & 1.22269 & 4 & 1 & 5 & 218 \\
\hline $\begin{array}{l}\text { 12. Using a formal approach to identify why } \\
\text { employees stay at the organization. }\end{array}$ & 71 & 0 & 3.1268 & 4 & 1.19439 & 4 & 1 & 5 & 222 \\
\hline $\begin{array}{l}\text { 13. A strategy or plan is in place to deal with } \\
\text { competitors' attempt to recruit employees away } \\
\text { from the organization. }\end{array}$ & 71 & 0 & 3.1408 & 4 & 1.13761 & 4 & 1 & 5 & 223 \\
\hline $\begin{array}{l}\text { 14. Your organization currently allocated a formal } \\
\text { budget in place for employees' retention. }\end{array}$ & 71 & 0 & 3.1127 & 3 & 1.10259 & 4 & 1 & 5 & 221 \\
\hline $\begin{array}{l}\text { 15. It is expected that budget for retaining } \\
\text { employees will change over the next three } \\
\text { years. }\end{array}$ & 71 & 0 & 3.1268 & 4 & 1.14555 & 4 & 1 & 5 & 222 \\
\hline
\end{tabular}


Reda M. A. Gadelrab

Table 5: A Descriptive Analysis for "Development of Talents" Statements

\begin{tabular}{|c|c|c|c|c|c|c|c|c|c|}
\hline \multirow{2}{*}{ Item } & \multicolumn{2}{|c|}{$\mathbf{N}$} & \multirow{2}{*}{ Mean } & \multirow{2}{*}{ Mode } & \multirow{2}{*}{$\begin{array}{l}\text { Std. } \\
\text { Deviation }\end{array}$} & \multirow{2}{*}{ Range } & \multirow{2}{*}{ Minimum } & \multirow{2}{*}{ Maximum } & \multirow{2}{*}{ Sum } \\
\hline & Valid & Missing & & & & & & & \\
\hline $\begin{array}{l}\text { 1. Building a deeper reservoir of successors at every } \\
\text { level. }\end{array}$ & 71 & 0 & 3.2676 & 4 & 1.08177 & 4 & 1 & 5 & 232 \\
\hline 2. Creating a culture that values employees' work. & 71 & 0 & 3.5493 & 4 & 0.85838 & 4 & 1 & 5 & 252 \\
\hline $\begin{array}{l}\text { 3. Creating policies that encourage career growth and } \\
\text { development opportunities. }\end{array}$ & 71 & 0 & 3.2394 & 4 & 0.88584 & 4 & 1 & 5 & 230 \\
\hline $\begin{array}{l}\text { 4. Creating an environment where employees' ideas are } \\
\text { listened to and valued. }\end{array}$ & 71 & 0 & 2.9577 & 3 & 0.97741 & 4 & 1 & 5 & 210 \\
\hline $\begin{array}{l}\text { 5. Providing current employees with adequate training } \\
\text { that allows them to do their jobs well. }\end{array}$ & 71 & 0 & 3.1127 & 4 & 1.17776 & 4 & 1 & 5 & 221 \\
\hline $\begin{array}{l}\text { 6. Making employees feel empowered to make } \\
\text { decisions that affect their work. }\end{array}$ & 71 & 0 & 3.1972 & 4 & 1.19067 & 4 & 1 & 5 & 227 \\
\hline $\begin{array}{l}\text { 7. Conducting formal performance appraisals on a } \\
\text { regular basis (quarterly; biannually; annually). }\end{array}$ & 71 & 0 & 3.1549 & 3 & 1.32717 & 4 & 1 & 5 & 224 \\
\hline $\begin{array}{l}\text { 8. Conducting regular employee surveys (quarterly; } \\
\text { biannually; annually). }\end{array}$ & 71 & 0 & 3.1831 & 4 & 1.1124 & 4 & 1 & 5 & 226 \\
\hline $\begin{array}{l}\text { 9. Using a formal approach to track potential leaders' } \\
\text { performance. }\end{array}$ & 71 & 0 & 3.2394 & 4 & 1.12713 & 4 & 1 & 5 & 230 \\
\hline 10. Using a formal approach to identify potential leaders. & 71 & 0 & 3.0845 & 4 & 1.19219 & 4 & 1 & 5 & 219 \\
\hline $\begin{array}{l}\text { 11. Employees upgraded for higher positions are } \\
\text { assessed against competencies and qualifications } \\
\text { required to be successful in that position. }\end{array}$ & 71 & 0 & 3.1408 & 4 & 1.0993 & 4 & 1 & 5 & 223 \\
\hline $\begin{array}{l}\text { 12. Junior or mid-level employees are prepared to step } \\
\text { into senior leadership positions. }\end{array}$ & 71 & 0 & 3.2535 & 4 & 1.09177 & 4 & 1 & 5 & 231 \\
\hline $\begin{array}{l}\text { 13. Your organization currently allocated a formal } \\
\text { budget in place for developing employees. }\end{array}$ & 71 & 0 & 3.0704 & 4 & 1.22269 & 4 & 1 & 5 & 218 \\
\hline $\begin{array}{l}\text { 14. It is expected that budget for developing employees } \\
\text { will change over the next three years. }\end{array}$ & 71 & 0 & 3.5775 & 4 & 0.83942 & 4 & 1 & 5 & 254 \\
\hline $\begin{array}{l}\text { 15. Preparing current employees for advancement } \\
\text { opportunities. }\end{array}$ & 71 & 0 & 3.1127 & 4 & 0.8872 & 3 & 1 & 4 & 221 \\
\hline $\begin{array}{l}\text { 16. Preparing current employees to improve } \\
\text { performance to surpass expectations. }\end{array}$ & 71 & 0 & 3.1127 & 3 & 1.02189 & 4 & 1 & 5 & 221 \\
\hline
\end{tabular}


Exploring the Impact of Talent Management on the Organizational Effectiveness in the Egyptian Hospitality Industry

Table 6: A Descriptive Analysis for "Organizational Effectiveness" Statements

\begin{tabular}{|c|c|c|c|c|c|c|c|c|c|}
\hline \multirow{2}{*}{ Item } & \multicolumn{2}{|c|}{$\mathbf{N}$} & \multirow{2}{*}{ Mean } & \multirow{2}{*}{ Mode } & \multirow{2}{*}{$\begin{array}{c}\text { Std. } \\
\text { Deviation }\end{array}$} & \multirow{2}{*}{ Range } & \multirow{2}{*}{ Minimum } & \multirow{2}{*}{ Maximum } & \multirow{2}{*}{ Sum } \\
\hline & Valid & Missing & & & & & & & \\
\hline $\begin{array}{l}\text { 1. The organization is concerned with } \\
\text { increasing revenues to achieve employees' } \\
\text { satisfaction. }\end{array}$ & 71 & 0 & 3.4789 & 4 & 0.79028 & 3 & 2 & 5 & 247 \\
\hline $\begin{array}{l}\text { 2. The Management seeks to improve the level } \\
\text { of wages and incentives to increase } \\
\text { employees' satisfaction. }\end{array}$ & 71 & 0 & 3.1831 & 4 & 1.03247 & 4 & 1 & 5 & 226 \\
\hline $\begin{array}{l}\text { 3. The organization seeks to achieve consumer } \\
\text { satisfaction through providing quality } \\
\text { products at reasonable prices. }\end{array}$ & 71 & 0 & 2.9014 & 3 & 0.94347 & 4 & 1 & 5 & 206 \\
\hline $\begin{array}{l}\text { 4. The organization achieves high growth rates } \\
\text { of sales. }\end{array}$ & 71 & 0 & 3.2394 & 4 & 1.04833 & 4 & 1 & 5 & 230 \\
\hline $\begin{array}{l}\text { 5. Increasing profitability is the fundamental } \\
\text { goal for the management of the } \\
\text { organization. }\end{array}$ & 71 & 0 & 3.2113 & 4 & 1.06792 & 4 & 1 & 5 & 228 \\
\hline $\begin{array}{l}\text { 6. The organization continuously achieves } \\
\text { increases in new products to meet the needs } \\
\text { and desires of its customers. }\end{array}$ & 71 & 0 & 3.0845 & 4 & 1.30654 & 4 & 1 & 5 & 219 \\
\hline $\begin{array}{l}\text { 7. The organization seeks to increase market } \\
\text { share through high quality products } \\
\text { compared to competitors' products. }\end{array}$ & 71 & 0 & 3.3662 & 4 & 1.0315 & 4 & 1 & 5 & 239 \\
\hline $\begin{array}{l}\text { 8. Increase Loyalty and affiliation of } \\
\text { employees for the organization achieves } \\
\text { stability in the workforce and decreases } \\
\text { employees' turnover. }\end{array}$ & 71 & 0 & 3.1831 & 4 & 1.07318 & 4 & 1 & 5 & 226 \\
\hline $\begin{array}{l}\text { 9. The percentage of employees leaving their } \\
\text { jobs in the organization is fewer compared } \\
\text { to other organizations. }\end{array}$ & 71 & 0 & 3.2535 & 4 & 1.09177 & 4 & 1 & 5 & 231 \\
\hline $\begin{array}{l}\text { 10. Keeping up with the up to date technology } \\
\text { and technicality. }\end{array}$ & 71 & 0 & 3.1408 & 4 & 0.9456 & 3 & 2 & 5 & 223 \\
\hline
\end{tabular}


Regarding the relationships between Identification of Talents and Organizational Effectiveness, it was found that there were strong highly positive correlations among all the four statements for Identification of Talents and all the ten statements of Organizational Effectiveness as shown in Table 7. For example, There is a strong positive significant correlations (Pearson rho; $r=0.721 ; p=0.000$ ) between Identification of Talents statement one (ITS1) "Skills, abilities, experiences and qualifications needed for selection are identified according to strategy, goals and culture of the organization" and Organizational Effectiveness statement one (OES1) "The organization is concerned with increasing revenues to achieve employees' satisfaction". This indicates that the more adherence and referring to the strategy, goals and culture of the organization when identifying skills, abilities and qualifications needed for selection, the more achievement of employees' satisfaction through organization commitment to revenue increase.

Table 7: Correlations between Identification of Talents and Organizational Effectiveness

\begin{tabular}{|c|c|c|c|c|c|}
\hline & & ITS1 & ITS2 & ITS3 & ITS4 \\
\hline OES1 & $\begin{array}{r}\text { Pearson Correlation } \\
\text { Sig. (2-tailed) } \\
\mathrm{N}\end{array}$ & $\begin{array}{c}.721(* *) \\
.000 \\
71\end{array}$ & $\begin{array}{c}.760(* *) \\
.000 \\
71\end{array}$ & $\begin{array}{c}.691(* *) \\
.000 \\
71\end{array}$ & $\begin{array}{c}.713(* *) \\
.000 \\
71\end{array}$ \\
\hline OES2 & $\begin{array}{r}\text { Pearson Correlation } \\
\text { Sig. (2-tailed) } \\
\mathrm{N}\end{array}$ & $\begin{array}{c}.723(* *) \\
.000 \\
71 \\
\end{array}$ & $\begin{array}{c}.762(* *) \\
.000 \\
71 \\
\end{array}$ & $\begin{array}{c}.724(* *) \\
.000 \\
71 \\
\end{array}$ & $\begin{array}{c}.766(* *) \\
.000 \\
71 \\
\end{array}$ \\
\hline OES3 & $\begin{array}{r}\text { Pearson Correlation } \\
\text { Sig. (2-tailed) } \\
\mathrm{N}\end{array}$ & $\begin{array}{c}.544(* *) \\
.000 \\
71\end{array}$ & $\begin{array}{c}.548(* *) \\
.000 \\
71\end{array}$ & $\begin{array}{c}.602(* *) \\
.000 \\
71\end{array}$ & $\begin{array}{c}.569(* *) \\
.000 \\
71\end{array}$ \\
\hline OES4 & $\begin{array}{r}\text { Pearson Correlation } \\
\text { Sig. (2-tailed) } \\
\mathrm{N}\end{array}$ & $\begin{array}{c}.786(* *) \\
.000 \\
71\end{array}$ & $\begin{array}{c}.809(* *) \\
.000 \\
71\end{array}$ & $\begin{array}{c}.683(* *) \\
.000 \\
71\end{array}$ & $\begin{array}{c}.812(* *) \\
.000 \\
71\end{array}$ \\
\hline OES5 & $\begin{array}{r}\text { Pearson Correlation } \\
\text { Sig. (2-tailed) } \\
\mathrm{N}\end{array}$ & $\begin{array}{c}.638(* *) \\
.000 \\
71 \\
\end{array}$ & $\begin{array}{c}.560(* *) \\
.000 \\
71\end{array}$ & $\begin{array}{c}.641(* *) \\
.000 \\
71\end{array}$ & $\begin{array}{c}.613(* *) \\
.000 \\
71\end{array}$ \\
\hline OES6 & $\begin{array}{r}\text { Pearson Correlation } \\
\text { Sig. (2-tailed) } \\
\mathrm{N}\end{array}$ & $\begin{array}{c}.675(* *) \\
.000 \\
71 \\
\end{array}$ & $\begin{array}{c}.663(* *) \\
.000 \\
71\end{array}$ & $\begin{array}{c}.631(* *) \\
.000 \\
71\end{array}$ & $\begin{array}{c}.681(* *) \\
.000 \\
71\end{array}$ \\
\hline OES7 & $\begin{array}{r}\text { Pearson Correlation } \\
\text { Sig. (2-tailed) } \\
\mathrm{N}\end{array}$ & $\begin{array}{c}.623(* *) \\
.000 \\
71\end{array}$ & $\begin{array}{c}.693(* *) \\
.000 \\
71\end{array}$ & $\begin{array}{c}.635(* *) \\
.000 \\
71\end{array}$ & $\begin{array}{c}.731(* *) \\
.000 \\
71\end{array}$ \\
\hline OES8 & $\begin{array}{r}\text { Pearson Correlation } \\
\text { Sig. (2-tailed) } \\
\mathrm{N}\end{array}$ & $\begin{array}{c}.590(* *) \\
.000 \\
71\end{array}$ & $\begin{array}{c}.686(* *) \\
.000 \\
71\end{array}$ & $\begin{array}{c}.593(* *) \\
.000 \\
71\end{array}$ & $\begin{array}{c}.684(* *) \\
.000 \\
71 \\
\end{array}$ \\
\hline OES9 & $\begin{array}{r}\text { Pearson Correlation } \\
\text { Sig. (2-tailed) } \\
\mathrm{N}\end{array}$ & $\begin{array}{c}.621(* *) \\
.000 \\
71\end{array}$ & $\begin{array}{c}.652(* *) \\
.000 \\
71\end{array}$ & $\begin{array}{c}.656(* *) \\
.000 \\
71\end{array}$ & $\begin{array}{c}.654(* *) \\
.000 \\
71\end{array}$ \\
\hline OES10 & $\begin{array}{r}\text { Pearson Correlation } \\
\text { Sig. (2-tailed) } \\
\mathrm{N}\end{array}$ & $\begin{array}{c}.674(* *) \\
.000 \\
71\end{array}$ & $\begin{array}{c}.731(* *) \\
.000 \\
71\end{array}$ & $\begin{array}{c}.655(* *) \\
.000 \\
71\end{array}$ & $\begin{array}{c}.750(* *) \\
.000 \\
71\end{array}$ \\
\hline
\end{tabular}

Regarding the relationship between Attraction of Talents and Organizational Effectiveness, it was revealed that there were strong highly positive correlations among all 15 statements in Talents Attraction and all ten statements of the Organizational Effectiveness as seen in Table 8. For example, There is a strong positive significant correlations (Pearson rho; $r=0.586 ; \mathrm{p}=0.000$ ) between Attraction of Talents statement one (ATS1) "There are specific and clear instructions to attract talents" and Organizational Effectiveness statement one (OES1) "The organization is concerned with increasing revenues to achieve employees' satisfaction". This reveals that the more existence of specific and clear instructions for the talents attraction, the more achievement of employees' satisfaction through organization commitment to revenue increases. 


\section{Exploring the Impact of Talent Management on the Organizational Effectiveness in the Egyptian Hospitality Industry}

In terms of the relationship between Retention of Talents and Organizational Effectiveness, it was found that there were strong highly positive correlations among all 15 statements of Talents Retention and all ten statements of the Organizational Effectiveness as illustrated in Table 9. For example, There is a strong positive significant correlations (Pearson rho; $r=0.721 ; p=0.000$ ) between Retaining Talents statement one (RTS1) "Aligning employees with the mission and vision of the organization" and Organizational Effectiveness statement one (OES1) "The organization is concerned with increasing revenues to achieve employees' satisfaction". This means that the more alignment of employees with the vision and mission of the organization, the more achievement of employees' satisfaction through organization commitment to revenue increase.

Considering the relationship between Development of Talents and Organizational Effectiveness, it was revealed that there were strong highly positive correlations among all 16 statements of Talents Development and all ten statements of Organizational Effectiveness as illustrated in Table 10. For example, There is a strong positive significant correlations (Pearson rho; $r=0.717 ; p=0.000$ ) between Developing Talents statement one (DTS1) "Building a deeper reservoir of successors at every level" and Organizational Effectiveness statement one (OES1) "The organization is concerned with increasing revenues to achieve employees' satisfaction". This indicates that the more focus on building a deeper reservoir of talents at every level in organization, the more achievement of employees' satisfaction through organization commitment to revenue increase.

Differences among Hotel categories and Management Level in terms of Talent Management and Organizational Effectiveness:

The findings in Appendix 1 reveal the differences among hotel categories (i.e., five and four star hotels) scores with regard to Talent Management and Organizational effectiveness. Whereas the results illustrated in Appendix 2; show the differences among management level (i.e. senior and middle) relating to Talent Management and Organizational effectiveness.

Considering variances among hotel categories in terms of Talent Management four sections and Organizational Effectiveness section in the questionnaire, it was found that there were no statistically significant differences in all five sections of the questionnaire scores between five and four star hotels as shown in Appendix 1. For example, in ITS1, the $\mathrm{Z}$ value is -0.50083 (rounded) of a significance level (Asymp. Sig., 2-tailed) of $\mathrm{p}=0.616494$. The probability values (p) is not less than or equal to 0.05 , so the difference is not significant. The Mean Rank for 55 questionnaires distributed to five star hotels is 35.40, as against 38.06 in the 16 questionnaires distributed to four star hotels. 
Table 8: Correlations between Attraction of Talents and Organizational Effectiveness

\begin{tabular}{|c|c|c|c|c|c|c|c|c|c|c|c|c|c|c|c|c|}
\hline & & ATS1 & ATS2 & ATS3 & ATS4 & ATS5 & ATS6 & ATS7 & ATS8 & ATS9 & ATS10 & ATS11 & ATS12 & ATS13 & ATS14 & ATS15 \\
\hline \multirow{3}{*}{ OES1 } & Pearson Correlation & $.586(* *)$ & $.717(* *)$ & $.721(* *)$ & $.738(* *)$ & $.653(* *)$ & $.666(* *)$ & $.706(* *)$ & $.571(* *)$ & $.750(* *)$ & $.724(* *)$ & $.703(* *)$ & $.729(* *)$ & $.720(* *)$ & $.652(* *)$ & $.691(* *)$ \\
\hline & Sig. (2-tailed) & .000 & .000 & .000 & .000 & .000 & .000 & .000 & .000 & .000 & .000 & .000 & .000 & .000 & .000 & .000 \\
\hline & $\mathrm{N}$ & 71 & 71 & 71 & 71 & 71 & 71 & 71 & 71 & 71 & 71 & 71 & 71 & 71 & 71 & 71 \\
\hline \multirow{3}{*}{ OES2 } & Pearson Correlation & $.606(* *)$ & $.664(* *)$ & $.639(* *)$ & $.639(* *)$ & $.698(* *)$ & $.698(* *)$ & $.666(* *)$ & $.533(* *)$ & $.763(* *)$ & $.814(* *)$ & $.688(* *)$ & $.775(* *)$ & $.675(* *)$ & $.618(* *)$ & $.650(* *)$ \\
\hline & Sig. (2-tailed) & .000 & .000 & .000 & .000 & .000 & .000 & .000 & .000 & .000 & .000 & .000 & .000 & .000 & .000 & .000 \\
\hline & $\mathrm{N}$ & 71 & 71 & 71 & 71 & 71 & 71 & 71 & 71 & 71 & 71 & 71 & 71 & 71 & 71 & 71 \\
\hline \multirow{3}{*}{ OES3 } & Pearson Correlation & $.572(* *)$ & $.585(* *)$ & $.617(* *)$ & $.528(* *)$ & $.512(* *)$ & $.432(* *)$ & $.617(* *)$ & $.505(* *)$ & $.566(* *)$ & $.472(* *)$ & $.565(* *)$ & $.522(* *)$ & $.651(* *)$ & $.600(* *)$ & $.546(* *)$ \\
\hline & Sig. (2-tailed) & .000 & .000 & .000 & .000 & .000 & .000 & .000 & .000 & .000 & .000 & .000 & .000 & .000 & .000 & .000 \\
\hline & $\mathrm{N}$ & 71 & 71 & 71 & 71 & 71 & 71 & 71 & 71 & 71 & 71 & 71 & 71 & 71 & 71 & 71 \\
\hline \multirow{3}{*}{ OES4 } & Pearson Correlation & $.707(* *)$ & $.787(* *)$ & $.773(* *)$ & $.680(* *)$ & $.721(* *)$ & $.748(* *)$ & $.731(* *)$ & $.696(* *)$ & $.842(* *)$ & $.871(* *)$ & $.677(* *)$ & $.788(* *)$ & $.730(* *)$ & $.703(* *)$ & $.710(* *)$ \\
\hline & Sig. (2-tailed) & .000 & .000 & .000 & .000 & .000 & .000 & .000 & .000 & .000 & .000 & .000 & .000 & .000 & .000 & .000 \\
\hline & $\mathrm{N}$ & 71 & 71 & 71 & 71 & 71 & 71 & 71 & 71 & 71 & 71 & 71 & 71 & 71 & 71 & 71 \\
\hline \multirow{3}{*}{ OES5 } & Pearson Correlation & $.579(* *)$ & $.595(* *)$ & $.682(* *)$ & $.603(* *)$ & $.547(* *)$ & $.478(* *)$ & $.548(* *)$ & $.582(* *)$ & $.652(* *)$ & $.678(* *)$ & $.549(* *)$ & $.651(* *)$ & $.709(* *)$ & $.650(* *)$ & $.645(* *)$ \\
\hline & Sig. (2-tailed) & .000 & .000 & .000 & .000 & .000 & .000 & .000 & .000 & .000 & .000 & .000 & .000 & .000 & .000 & .000 \\
\hline & $\mathrm{N}$ & 71 & 71 & 71 & 71 & 71 & 71 & 71 & 71 & 71 & 71 & 71 & 71 & 71 & 71 & 71 \\
\hline \multirow{3}{*}{ OES6 } & Pearson Correlation & $.724(* *)$ & $.725(* *)$ & $.693(* *)$ & $.597(* *)$ & $.630(* *)$ & $.636(* *)$ & $.623(* *)$ & $.710(* *)$ & $.687(* *)$ & $.750(* *)$ & $.593(* *)$ & $.707(* *)$ & $.695(* *)$ & $.739(* *)$ & $.763(* *)$ \\
\hline & Sig. (2-tailed) & .000 & .000 & .000 & .000 & .000 & .000 & .000 & .000 & .000 & .000 & .000 & .000 & .000 & .000 & .000 \\
\hline & $\mathrm{N}$ & 71 & 71 & 71 & 71 & 71 & 71 & 71 & 71 & 71 & 71 & 71 & 71 & 71 & 71 & 71 \\
\hline \multirow{3}{*}{ OES7 } & Pearson Correlation & $.776(* *)$ & $.681(* *)$ & $.777(* *)$ & $.655(* *)$ & $.658(* *)$ & $.605(* *)$ & $.617(* *)$ & $.566(* *)$ & $.690(* *)$ & $.710(* *)$ & $.625(* *)$ & $.765(* *)$ & $.696(* *)$ & $.673(* *)$ & $.654(* *)$ \\
\hline & Sig. (2-tailed) & .000 & .000 & .000 & .000 & .000 & .000 & .000 & .000 & .000 & .000 & .000 & .000 & .000 & .000 & .000 \\
\hline & $\mathrm{N}$ & 71 & 71 & 71 & 71 & 71 & 71 & 71 & 71 & 71 & 71 & 71 & 71 & 71 & 71 & 71 \\
\hline \multirow{3}{*}{ OES8 } & Pearson Correlation & $.523(* *)$ & $.603(* *)$ & $.537(* *)$ & $.563(* *)$ & $.726(* *)$ & $.695(* *)$ & $.641(* *)$ & $.433(* *)$ & $.570(* *)$ & $.640(* *)$ & $.490(* *)$ & $.663(* *)$ & $.540(* *)$ & $.606(* *)$ & $.566(* *)$ \\
\hline & Sig. (2-tailed) & .000 & .000 & .000 & .000 & .000 & .000 & .000 & .000 & .000 & .000 & .000 & .000 & .000 & .000 & .000 \\
\hline & $\mathrm{N}$ & 71 & 71 & 71 & 71 & 71 & 71 & 71 & 71 & 71 & 71 & 71 & 71 & 71 & 71 & 71 \\
\hline \multirow{3}{*}{ OES9 } & Pearson Correlation & $.616(* *)$ & $.548(* *)$ & $.575(* *)$ & $.587(* *)$ & $.731(* *)$ & $.650(* *)$ & $.655(* *)$ & $.487(* *)$ & $.639(* *)$ & $.692(* *)$ & $.582(* *)$ & $.648(* *)$ & $.651(* *)$ & $.633(* *)$ & $.621(* *)$ \\
\hline & Sig. (2-tailed) & .000 & .000 & .000 & .000 & .000 & .000 & .000 & .000 & .000 & .000 & .000 & .000 & .000 & .000 & .000 \\
\hline & $\mathrm{N}$ & 71 & 71 & 71 & 71 & 71 & 71 & 71 & 71 & 71 & 71 & 71 & 71 & 71 & 71 & 71 \\
\hline \multirow{3}{*}{ OES10 } & Pearson Correlation & $.673(* *)$ & $.737(* *)$ & $.716(* *)$ & $.642(* *)$ & $.706(* *)$ & $.723(* *)$ & $.721(* *)$ & $.677(* *)$ & $.692(* *)$ & $.742(* *)$ & $.648(* *)$ & $.802(* *)$ & $.758(* *)$ & $.678(* *)$ & $.667(* *)$ \\
\hline & Sig. (2-tailed) & .000 & .000 & .000 & .000 & .000 & .000 & .000 & .000 & .000 & .000 & .000 & .000 & .000 & .000 & .000 \\
\hline & $\mathrm{N}$ & 71 & 71 & 71 & 71 & 71 & 71 & 71 & 71 & 71 & 71 & 71 & 71 & 71 & 71 & 71 \\
\hline
\end{tabular}

\footnotetext{
* Correlation is highly significant at 0.01 level (2-tailed).
} 
Exploring the Impact of Talent Management on the Organizational Effectiveness in the Egyptian Hospitality Industry

Table 9: Correlations between Retention of Talents and Organizational Effectiveness

\begin{tabular}{|c|c|c|c|c|c|c|c|c|c|c|c|c|c|c|c|c|}
\hline & & RTS1 & RTS2 & RTS3 & RTS4 & RTS5 & RTS6 & RTS7 & RTS8 & RTS9 & RTS10 & RTS11 & RTS12 & RTS13 & RTS14 & RTS15 \\
\hline \multirow{3}{*}{ OES1 } & Pearson Correlation & $.721(* *)$ & $.720(* *)$ & $.621(* *)$ & $.694(* *)$ & $.732(* *)$ & $.769(* *)$ & $.766(* *)$ & $.551(* *)$ & $.641(* *)$ & $.639(* *)$ & $.645(* *)$ & $.555(* *)$ & $.623(* *)$ & $.560(* *)$ & $.753(* *)$ \\
\hline & Sig. (2-tailed) & .000 & .000 & .000 & .000 & .000 & .000 & .000 & .000 & .000 & .000 & .000 & .000 & .000 & .000 & .000 \\
\hline & $\mathrm{N}$ & 71 & 71 & 71 & 71 & 71 & 71 & 71 & 71 & 71 & 71 & 71 & 71 & 71 & 71 & 71 \\
\hline \multirow{3}{*}{ OES2 } & Pearson Correlation & $.695(* *)$ & $.725(* *)$ & $.589(* *)$ & $.679(* *)$ & $.758(* *)$ & $.796(* *)$ & $.805(* *)$ & $.569(* *)$ & $.688(* *)$ & $.643(* *)$ & $.646(* *)$ & $.630(* *)$ & $.695(* *)$ & $.647(* *)$ & $.789(* *)$ \\
\hline & Sig. (2-tailed) & .000 & .000 & .000 & .000 & .000 & .000 & .000 & .000 & .000 & .000 & .000 & .000 & .000 & .000 & .000 \\
\hline & $\mathrm{N}$ & 71 & 71 & 71 & 71 & 71 & 71 & 71 & 71 & 71 & 71 & 71 & 71 & 71 & 71 & 71 \\
\hline \multirow{3}{*}{ OES3 } & Pearson Correlation & $.515(* *)$ & $.624(* *)$ & $.463(* *)$ & $.457(* *)$ & $.555(* *)$ & $.547(* *)$ & $.564(* *)$ & $.507(* *)$ & $.475(* *)$ & $.563(* *)$ & $.551(* *)$ & $.480(* *)$ & $.452(* *)$ & $.450(* *)$ & $.514(* *)$ \\
\hline & Sig. (2-tailed) & .000 & .000 & .000 & .000 & .000 & .000 & .000 & .000 & .000 & .000 & .000 & .000 & .000 & .000 & .000 \\
\hline & $\mathrm{N}$ & 71 & 71 & 71 & 71 & 71 & 71 & 71 & 71 & 71 & 71 & 71 & 71 & 71 & 71 & 71 \\
\hline \multirow{3}{*}{ OES4 } & Pearson Correlation & $.677(* *)$ & $.755(* *)$ & $.587(* *)$ & $.722(* *)$ & $.813(* *)$ & $.777(* *)$ & $.839(* *)$ & $.605(* *)$ & $.773(* *)$ & $.718(* *)$ & $.745(* *)$ & $.763(* *)$ & $.690(* *)$ & $.718(* *)$ & $.736(* *)$ \\
\hline & Sig. (2-tailed) & .000 & .000 & .000 & .000 & .000 & .000 & .000 & .000 & .000 & .000 & .000 & .000 & .000 & .000 & .000 \\
\hline & $\mathrm{N}$ & 71 & 71 & 71 & 71 & 71 & 71 & 71 & 71 & 71 & 71 & 71 & 71 & 71 & 71 & 71 \\
\hline \multirow{3}{*}{ OES5 } & Pearson Correlation & $.500(* *)$ & $.575(* *)$ & $.392(* *)$ & $.522(* *)$ & $.684(* *)$ & $.674(* *)$ & $.628(* *)$ & $.580(* *)$ & $.613(* *)$ & $.658(* *)$ & $.601(* *)$ & $.651(* *)$ & $.575(* *)$ & $.489(* *)$ & $.527(* *)$ \\
\hline & Sig. (2-tailed) & .000 & .000 & .001 & .000 & .000 & .000 & .000 & .000 & .000 & .000 & .000 & .000 & .000 & .000 & .000 \\
\hline & $\mathrm{N}$ & 71 & 71 & 71 & 71 & 71 & 71 & 71 & 71 & 71 & 71 & 71 & 71 & 71 & 71 & 71 \\
\hline \multirow{3}{*}{ OES6 } & Pearson Correlation & $.558(* *)$ & $.606(* *)$ & $.516(* *)$ & $.653(* *)$ & $.732(* *)$ & $.671(* *)$ & $.702(* *)$ & $.484(* *)$ & $.694(* *)$ & $.668(* *)$ & $.730(* *)$ & $.689(* *)$ & $.617(* *)$ & $.559(* *)$ & $.651(* *)$ \\
\hline & Sig. (2-tailed) & .000 & .000 & .000 & .000 & .000 & .000 & .000 & .000 & .000 & .000 & .000 & .000 & .000 & .000 & .000 \\
\hline & $\mathrm{N}$ & 71 & 71 & 71 & 71 & 71 & 71 & 71 & 71 & 71 & 71 & 71 & 71 & 71 & 71 & 71 \\
\hline \multirow{3}{*}{ OES7 } & Pearson Correlation & $.610(* *)$ & $.683(* *)$ & $.527(* *)$ & $.595(* *)$ & $.729(* *)$ & $.668(* *)$ & $.748(* *)$ & $.467(* *)$ & $.631(* *)$ & $.673(* *)$ & $.761(* *)$ & $.669(* *)$ & $.686(* *)$ & $.566(* *)$ & $.698(* *)$ \\
\hline & Sig. (2-tailed) & .000 & .000 & .000 & .000 & .000 & .000 & .000 & .000 & .000 & .000 & .000 & .000 & .000 & .000 & .000 \\
\hline & $\mathrm{N}$ & 71 & 71 & 71 & 71 & 71 & 71 & 71 & 71 & 71 & 71 & 71 & 71 & 71 & 71 & 71 \\
\hline \multirow{3}{*}{ OES8 } & Pearson Correlation & $.642(* *)$ & $.686(* *)$ & $.598(* *)$ & $.629(* *)$ & $.601(* *)$ & $.567(* *)$ & $.646(* *)$ & $.451(* *)$ & $.576(* *)$ & $.598(* *)$ & $.567(* *)$ & $.695(* *)$ & $.587(* *)$ & $.646(* *)$ & $.527(* *)$ \\
\hline & Sig. (2-tailed) & .000 & .000 & .000 & .000 & .000 & .000 & .000 & .000 & .000 & .000 & .000 & .000 & .000 & .000 & .000 \\
\hline & $\mathrm{N}$ & 71 & 71 & 71 & 71 & 71 & 71 & 71 & 71 & 71 & 71 & 71 & 71 & 71 & 71 & 71 \\
\hline \multirow{3}{*}{ OES9 } & Pearson Correlation & $.632(* *)$ & $.734(* *)$ & $.500(* *)$ & $.622(* *)$ & $.676(* *)$ & $.706(* *)$ & $.718(* *)$ & $.548(* *)$ & $.571(* *)$ & $.697(* *)$ & $.586(* *)$ & $.654(* *)$ & $.592(* *)$ & $.617(* *)$ & $.636(* *)$ \\
\hline & Sig. (2-tailed) & .000 & .000 & .000 & .000 & .000 & .000 & .000 & .000 & .000 & .000 & .000 & .000 & .000 & .000 & .000 \\
\hline & $\mathrm{N}$ & 71 & 71 & 71 & 71 & 71 & 71 & 71 & 71 & 71 & 71 & 71 & 71 & 71 & 71 & 71 \\
\hline \multirow{3}{*}{ OES10 } & Pearson Correlation & $.640(* *)$ & $.744(* *)$ & $.615(* *)$ & $.666(* *)$ & $.793(* *)$ & $.693(* *)$ & $.744(* *)$ & $.535(* *)$ & $.700(* *)$ & $.723(* *)$ & $.696(* *)$ & $.730(* *)$ & $.672(* *)$ & $.601(* *)$ & $.643(* *)$ \\
\hline & Sig. (2-tailed) & .000 & .000 & .000 & .000 & .000 & .000 & .000 & .000 & .000 & .000 & .000 & .000 & .000 & .000 & .000 \\
\hline & $\mathrm{N}$ & 71 & 71 & 71 & 71 & 71 & 71 & 71 & 71 & 71 & 71 & 71 & 71 & 71 & 71 & 71 \\
\hline
\end{tabular}

** Correlation is highly significant at 0.01 level (2-tailed). 
Reda M. A. Gadelrab

Table 10: Correlations between Development of Talents and Organizational Effectiveness

\begin{tabular}{|c|c|c|c|c|c|c|c|c|c|c|c|c|c|c|c|c|c|}
\hline & & DTS1 & DTS2 & DTS3 & DTS4 & DTS5 & DTS6 & DTS7 & DTS8 & DTS9 & DTS10 & DTS11 & DTS12 & DTS13 & DTS14 & DTS15 & DTS16 \\
\hline \multirow{3}{*}{ OES1 } & Pearson Correlation & $.717(* *)$ & $.681(* *)$ & $.793(* *)$ & $.692(* *)$ & $.770(* *)$ & $.733(* *)$ & $.596(* *)$ & $.614(* *)$ & $.559(* *)$ & $.593(* *)$ & $.628(* *)$ & $.801(* *)$ & $.733(* *)$ & $.719(* *)$ & $.778(* *)$ & $.445(* *)$ \\
\hline & Sig. (2-tailed) & .000 & .000 & .000 & .000 & .000 & .000 & .000 & .000 & .000 & .000 & .000 & .000 & .000 & .000 & .000 & .000 \\
\hline & $\mathrm{N}$ & 71 & 71 & 71 & 71 & 71 & 71 & 71 & 71 & 71 & 71 & 71 & 71 & 71 & 71 & 71 & 71 \\
\hline \multirow{3}{*}{ OES2 } & Pearson Correlation & $.710(* *)$ & $.691(* *)$ & $.795(* *)$ & $.645(* *)$ & $.817(* *)$ & $.737(* *)$ & $.605(* *)$ & $.592(* *)$ & $.600(* *)$ & $.626(* *)$ & $.682(* *)$ & $.757(* *)$ & $.759(* *)$ & $.750(* *)$ & $.835(* *)$ & $.454(* *)$ \\
\hline & Sig. (2-tailed) & .000 & .000 & .000 & .000 & .000 & .000 & .000 & .000 & .000 & .000 & .000 & .000 & .000 & .000 & .000 & .000 \\
\hline & $\mathrm{N}$ & 71 & 71 & 71 & 71 & 71 & 71 & 71 & 71 & 71 & 71 & 71 & 71 & 71 & 71 & 71 & 71 \\
\hline \multirow{3}{*}{ OES3 } & Pearson Correlation & $.558(* *)$ & $.526(* *)$ & $.610(* *)$ & $.615(* *)$ & $.576(* *)$ & $.590(* *)$ & $.446(* *)$ & $.548(* *)$ & $.493(* *)$ & $.503(* *)$ & $.565(* *)$ & $.621(* *)$ & $.514(* *)$ & $.506(* *)$ & $.577(* *)$ & $.427(* *)$ \\
\hline & Sig. (2-tailed) & .000 & .000 & .000 & .000 & .000 & .000 & .000 & .000 & .000 & .000 & .000 & .000 & .000 & .000 & .000 & .000 \\
\hline & $\mathrm{N}$ & 71 & 71 & 71 & 71 & 71 & 71 & 71 & 71 & 71 & 71 & 71 & 71 & 71 & 71 & 71 & 71 \\
\hline \multirow{3}{*}{ OES4 } & Pearson Correlation & $.837(* *)$ & $.804(* *)$ & $.783(* *)$ & $.610(* *)$ & $.846(* *)$ & $.866(* *)$ & $.733(* *)$ & $.746(* *)$ & $.664(* *)$ & $.681(* *)$ & $.714(* *)$ & $.758(* *)$ & $.733(* *)$ & $.766(* *)$ & $.815(* *)$ & $.548(* *)$ \\
\hline & Sig. (2-tailed) & .000 & .000 & .000 & .000 & .000 & .000 & .000 & .000 & .000 & .000 & .000 & .000 & .000 & .000 & .000 & .000 \\
\hline & $\mathrm{N}$ & 71 & 71 & 71 & 71 & 71 & 71 & 71 & 71 & 71 & 71 & 71 & 71 & 71 & 71 & 71 & 71 \\
\hline \multirow{3}{*}{ OES5 } & Pearson Correlation & $.643(* *)$ & $.682(* *)$ & $.625(* *)$ & $.515(* *)$ & $.594(* *)$ & $.652(* *)$ & $.612(* *)$ & $.628(* *)$ & $.575(* *)$ & $.524(* *)$ & $.558(* *)$ & $.554(* *)$ & $.546(* *)$ & $.611(* *)$ & $.683(* *)$ & $.358(* *)$ \\
\hline & Sig. (2-tailed) & .000 & .000 & .000 & .000 & .000 & .000 & .000 & .000 & .000 & .000 & .000 & .000 & .000 & .000 & .000 & .002 \\
\hline & $\mathrm{N}$ & 71 & 71 & 71 & 71 & 71 & 71 & 71 & 71 & 71 & 71 & 71 & 71 & 71 & 71 & 71 & 71 \\
\hline \multirow{3}{*}{ OES6 } & Pearson Correlation & $.792(* *)$ & $.735(* *)$ & $.686(* *)$ & $.540(* *)$ & $.746(* *)$ & $.705(* *)$ & $.750(* *)$ & $.746(* *)$ & $.665(* *)$ & $.610(* *)$ & $.668(* *)$ & $.666(* *)$ & $.524(* *)$ & $.684(* *)$ & $.743(* *)$ & $.410(* *)$ \\
\hline & Sig. (2-tailed) & .000 & .000 & .000 & .000 & .000 & .000 & .000 & .000 & .000 & .000 & .000 & .000 & .000 & .000 & .000 & .000 \\
\hline & $\mathrm{N}$ & 71 & 71 & 71 & 71 & 71 & 71 & 71 & 71 & 71 & 71 & 71 & 71 & 71 & 71 & 71 & 71 \\
\hline \multirow{3}{*}{ OES7 } & Pearson Correlation & $.717(* *)$ & $.673(* *)$ & $.747(* *)$ & $.554(* *)$ & $.789(* *)$ & $.720(* *)$ & $.751(* *)$ & $.725(* *)$ & $.734(* *)$ & $.637(* *)$ & $.735(* *)$ & $.678(* *)$ & $.568(* *)$ & $.676(* *)$ & .719 (**) $^{(*)}$ & $.462(* *)$ \\
\hline & Sig. (2-tailed) & .000 & .000 & .000 & .000 & .000 & .000 & .000 & .000 & .000 & .000 & .000 & .000 & .000 & .000 & .000 & .000 \\
\hline & $\mathrm{N}$ & 71 & 71 & 71 & 71 & 71 & 71 & 71 & 71 & 71 & 71 & 71 & 71 & 71 & 71 & 71 & 71 \\
\hline \multirow{3}{*}{ OES8 } & Pearson Correlation & $.548(* *)$ & $.572(* *)$ & $.599(* *)$ & $.443(* *)$ & $.752(* *)$ & $.676(* *)$ & $.582(* *)$ & $.558(* *)$ & $.601(* *)$ & $.635(* *)$ & $.644(* *)$ & $.582(* *)$ & $.600(* *)$ & $.658(* *)$ & $.668(* *)$ & $.541(* *)$ \\
\hline & Sig. (2-tailed) & .000 & .000 & .000 & .000 & .000 & .000 & .000 & .000 & .000 & .000 & .000 & .000 & .000 & .000 & .000 & .000 \\
\hline & $\mathrm{N}$ & 71 & 71 & 71 & 71 & 71 & 71 & 71 & 71 & 71 & 71 & 71 & 71 & 71 & 71 & 71 & 71 \\
\hline \multirow{3}{*}{ OES9 } & Pearson Correlation & $.655(* *)$ & $.627(* *)$ & $.719(* *)$ & $.519(* *)$ & $.722(* *)$ & $.697(* *)$ & $.594(* *)$ & $.632(* *)$ & $.588(* *)$ & $.609(* *)$ & $.636(* *)$ & $.616(* *)$ & $.639(* *)$ & $.711(* *)$ & $.752(* *)$ & $.486(* *)$ \\
\hline & Sig. (2-tailed) & .000 & .000 & .000 & .000 & .000 & .000 & .000 & .000 & .000 & .000 & .000 & .000 & .000 & .000 & .000 & .000 \\
\hline & $\mathrm{N}$ & 71 & 71 & 71 & 71 & 71 & 71 & 71 & 71 & 71 & 71 & 71 & 71 & 71 & 71 & 71 & 71 \\
\hline \multirow{3}{*}{ OES10 } & Pearson Correlation & $.717(* *)$ & $.678(* *)$ & $.710(* *)$ & $.656(* *)$ & $.794(* *)$ & $.800(* *)$ & $.654(* *)$ & $.722(* *)$ & $.651(* *)$ & $.674(* *)$ & $.737(* *)$ & $.698(* *)$ & $.671(* *)$ & $.760(* *)$ & $.815(* *)$ & $.530(* *)$ \\
\hline & Sig. (2-tailed) & .000 & .000 & .000 & .000 & .000 & .000 & .000 & .000 & .000 & .000 & .000 & .000 & .000 & .000 & .000 & .000 \\
\hline & $\mathrm{N}$ & 71 & 71 & 71 & 71 & 71 & 71 & 71 & 71 & 71 & 71 & 71 & 71 & 71 & 71 & 71 & 71 \\
\hline
\end{tabular}

* Correlation is highly significant at 0.01 level (2-tailed). 

With regard to variances among managers level, i.e. senior or middle in relation to Talent Management four sections and Organizational Effectiveness section, it was noticed that there were no statistically significant differences in all five sections of the questionnaire scores of senior and middle managers as illustrated in Appendix 2. For example, in ITS1, the $\mathrm{Z}$ value is -0.218 (rounded) of a significance level (Asymp. Sig., 2tailed) of $p=0.827$. The probability values ( $p$ ) is not less than or equal to 0.05 , so the difference is not significant. The Mean Rank for the 30 questionnaire distributed to seniors was 36.57, as against 35.59 in the 41 questionnaires distributed to middle managers.

\section{Conclusion and Implications:}

The aim of this study was to explore the impact of talent management on enhancing the organizational effectiveness in the Egyptian Hospitality Industry through investigating ten five star hotels and six four star hotels to identify perspectives of 30 senior managers and 41 middle managers in the human resources department. The findings can be summarized as follows: (1) Strong statistically highly significant correlations were found among all four dimensions of talent management and organizational effectiveness, indicating a positive impact of the Talent Management on the Organizational Effectiveness; (2) No statistically significant differences have been noticed between hotel categories regarding talent management and organizational effectiveness; (3) No statistically significant differences have been detected between managers level related to talent management and organizational effectiveness. In general, it could be stated that talent management integrates with human resources procedures and has a strong impact on the organizational effectiveness.

\section{References:}

- Alleyne, P.; Doherty, L. and Greenidge, D. (2006) Approaches to HRM in the Barbados hotel industry. International Journal of Contemporary Hospitality Management, Vol. 18, No. 2, pp. 94109.

- Armstrong, M. (2012) Armstrong's Handbook of Human Resource Management Practice. $12^{\text {th }}$ ed. London: Kogan Page.

- Ashton, C. and Morton, L. (2005) Managing talent for competitive advantage: Taking a systemic approach to talent management. Strategic HR Review, Volume 4, No.5, pp. 28-31.

- Baum, T. (2008) Implications of hospitality and tourism labour markets for talent management strategies. International Journal of Contemporary Hospitality Management, Vol. 20, No. 7, pp.720 729.

- Beardwell, J. (2010) Talent Management. In Beardwell, J. and Claydon, T.(ed.) Human Resource Management: A Contemporary Approach, $6^{\text {th }}$ ed. London: Pearson.

- Brownell, J. (2010) Leadership in the Service of Hospitality, Cornell Hospitality Quarterly, Volume 51, No. 3, pp. 363-378.

- Chalkiti, K. and Sigala, M. (2010) Consequences of staff turnover Management strategies for addressing staff turnover in the Greek tourism industry: A comparison between insular and peninsular regions, International Journal of Contemporary Hospitality Management, Vol. 22, No. 3, pp. 335-359.

- Collins, A.B. (2007) Human resources: a hidden advantage? International Journal of Contemporary Hospitality Management, Vol. 19, No. 1, pp. 78-84.

- D'Annunzio-Green, N. (2008) Managing the talent management pipeline: Towards a greater understanding of senior managers' perspectives in the hospitality and tourism sector, International Journal of Contemporary Hospitality Management, Vol. 20, No. 7, pp. $807-819$.

- Davidson, M.C.G., Timo, N. and Wang, Y. (2010) How much does labour turnover cost?: A case study of Australian four- and five-star hotels, International Journal of Contemporary Hospitality Management, Vol. 22, No. 4, pp. 451-466.

- Deery, M. (2008) Talent management, work-life balance and retention strategies, International Journal of Contemporary Hospitality Management, Vol. 20, No. 7, pp. 792-806.

- Egyptian Hotel Association (2012) The Egyptian Hotel Guide, 32 ${ }^{\text {nd }}$ Ed., N.A., Egypt, PP. 60-65.

- Gadelrab, R. (2010) Managing Food Quality in Hotels: Integrated Quality Approaches to Food Production. Ph.D. thesis, University of Wales Institute, Cardiff, UK. 


\section{Exploring the Impact of Talent Management on the Organizational Effectiveness in the Egyptian Hospitality Industry}

- Gallardo, E.; Sánchez-Cañizares,S-M.; López-Guzmán,T. and Jesus, M.M. N. (2010) Employee satisfaction in the Iberian hotel industry: The case of Andalusia (Spain) and the Algarve (Portugal), International Journal of Contemporary Hospitality Management, Vol. 22, No. 3, pp. 321-334.

- Garlick, R. (2010) Do Happy Employees Really Mean Happy Customers? Or Is There More to the Equation? Cornell Hospitality Quarterly, Volume 51, No. 3, pp. 304-307.

- Gill, A., Fitzgerald, S., Bhutani, S., Mand, H. and Sharma, S. (2011) The relationship between transformational leadership and employee desire for empowerment, International Journal of Contemporary Hospitality Management, Vol. 22, No. 2, pp. 263-273.

- Gu, Z. and Siu, R.C.S. (2009) Drivers of job satisfaction as related to work performance in Macao casino hotels: An investigation based on employee survey, International Journal of Contemporary Hospitality Management, Vol. 21, No. 5, pp. 561-578.

- Iles, P.; Chuai, X. and Preece D. (2010) Talent Management and HRM in Multinational companies in Beijing: Definitions, differences and drivers. Journal of World Business, Vol. 46, No. 2, pp. $147-$ 158.

- Lewis, R. E. and Heckman, R. J. (2006) Talent Management: A Critical Review. Human Resource Management Review, Vol. 16, pp. 139-154.

- Martin, A.; Mactaggart, D. and Bowden, J. (2006) The barriers to the recruitment and retention of supervisors/managers in the Scottish tourism industry. International Journal of Contemporary Hospitality Management, Vol. 18, No. 5, pp. 380-97.

- Maxwell, G.A. and MacLean, S. (2008) Talent management in hospitality and tourism in Scotland: Operational implications and strategic actions, International Journal of Contemporary Hospitality Management, Vol. 20, No. 7, pp. 820-830.

- Nassar, M. (2012) Exploring current benchmarking practices in the Egyptian hotel sector, Benchmarking: An International Journal, Vol. 19, No. 6, pp. 730-742.

- Pelit, E.; Öztürk, Y. and Arslantürk, Y. (2011) The effects of employee empowerment on employee job satisfaction: A study on hotels in Turkey, International Journal of Contemporary Hospitality Management, Vol. 23, No. 6, pp. 784-802.

- Raub, S.; Alvarez, L. and Khanna, R. (2006) The different roles of corporate and unit level human resources managers in the hospitality industry, International Journal of Contemporary Hospitality Management, Vol. 18, No. 2, pp. 135-144.

- Robinson, R. N.S.; Arcodia, C. V.; Tian, C. and Charlton, P. (2010) Cookery-related employment vacancy advertisements and skills shortages, International Journal of Contemporary Hospitality Management, Vol. 22, No. 4, pp. 483-499.

- Scott, B. and Revis, S. (2008) Talent management in hospitality: graduate career success and strategies, International Journal of Contemporary Hospitality Management, Vol. 20, No. 7, pp. 781791.

- Tews, M. J. and Tracey, J. B. (2009) Helping Managers Help Themselves: The Use and Utility of On-the-Job Interventions to Improve the Impact of Interpersonal Skills Training, Cornell Hospitality Quarterly, Vol. 50, No. 2, pp. 245-258.

- Vural, Y.; Vardarlier, P. and Aykir, A. (2012) The Effects of Using Talent Management With Performance Evaluation System Over Employee Commitment. Social and Behavioral Sciences, Vol. 58 , pp. $340-349$.

- Watson, S. (2011) Where are we now? A review of management development issues in the hospitality and tourism sector: Implications for talent management, International Journal of Contemporary Hospitality Management, Vol. 20, No. 7, pp. 758-780.

- Wikipedia (2013) Talent Available from: ://en.wikipedia.org/wiki/Talent_management. Accessed 7, Jan., 2013. 
Reda M. A. Gadelrab

\section{Appendices:}

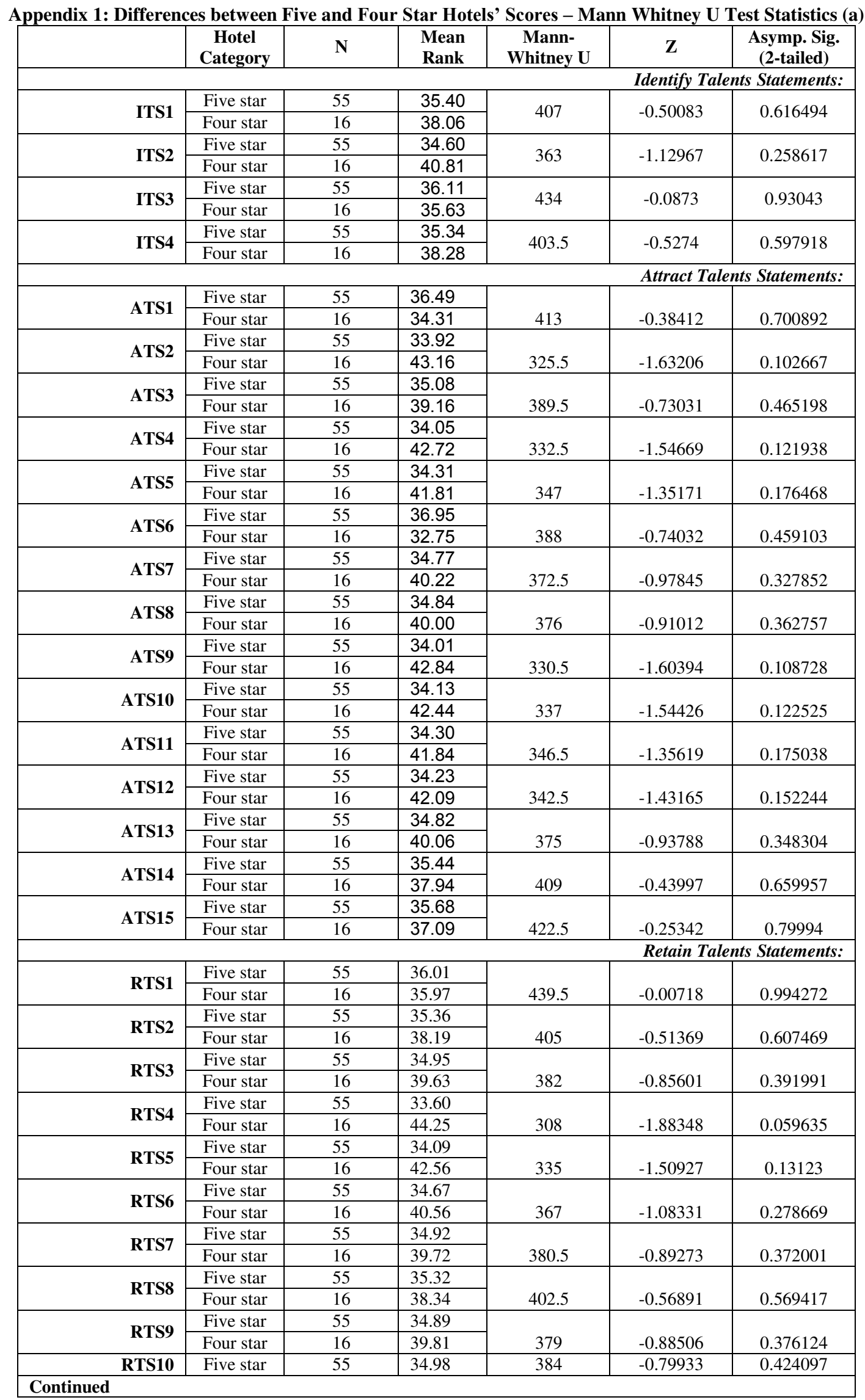


Exploring the Impact of Talent Management on the Organizational Effectiveness in the Egyptian Hospitality Industry

\begin{tabular}{|c|c|c|c|c|c|c|}
\hline & & & & & \multicolumn{2}{|c|}{ Appendix 1: Continued } \\
\hline & Four star & 16 & 39.50 & & & \\
\hline \multirow{2}{*}{ RTS11 } & Five star & 55 & 34.89 & \multirow[b]{2}{*}{379} & \multirow[b]{2}{*}{-0.86411} & \multirow[b]{2}{*}{0.387526} \\
\hline & Four star & 16 & 39.81 & & & \\
\hline \multirow{2}{*}{ RTS12 } & Five star & 55 & 35.53 & \multirow[b]{2}{*}{414} & \multirow[b]{2}{*}{-0.37674} & \multirow[b]{2}{*}{0.706369} \\
\hline & Four star & 16 & 37.63 & & & \\
\hline \multirow{2}{*}{ RTS13 } & Five star & 55 & 37.12 & \multirow[b]{2}{*}{378.5} & \multirow[b]{2}{*}{-0.882} & \multirow[b]{2}{*}{0.377776} \\
\hline & Four star & 16 & 32.16 & & & \\
\hline PTS14 & Five star & 55 & 34.28 & & & \\
\hline R1S14 & Four star & 16 & 41.91 & 345.5 & -1.3519 & 0.176406 \\
\hline DTC15 & Five star & 55 & 34.04 & & & \\
\hline Risis & Four star & 16 & 42.75 & 332 & -1.54425 & 0.122528 \\
\hline & & & & & Develop $T$ & ts Statements: \\
\hline & Five star & 55 & 34.40 & & & \\
\hline DTS1 & Four star & 16 & 41.50 & 352 & -1.294 & 0.195667 \\
\hline DTS? & Five star & 55 & 34.30 & & & \\
\hline DIS2 & Four star & 16 & 41.84 & 346.5 & -1.45645 & 0.145269 \\
\hline & Five star & 55 & 33.75 & & & \\
\hline DTS3 & Four star & 16 & 43.72 & 316.5 & -1.83239 & 0.066893 \\
\hline DTS4 & Five star & 55 & 33.69 & & & \\
\hline D1S4 & Four star & 16 & 43.94 & 313 & -1.89669 & 0.057869 \\
\hline & Five star & 55 & 35.26 & & & \\
\hline DTS5 & Four star & 16 & 38.53 & 399.5 & -0.59334 & 0.552951 \\
\hline DTS6 & Five star & 55 & 35.45 & & & \\
\hline DIS6 & Four star & 16 & 37.88 & 410 & -0.42754 & 0.668983 \\
\hline & Five star & 55 & 34.94 & & & \\
\hline DTS7 & Four star & 16 & 39.66 & 381.5 & -0.82346 & 0.410245 \\
\hline DTS\& & Five star & 55 & 35.27 & & & \\
\hline WTSO & Four star & 16 & 38.50 & 400 & -0.57868 & 0.562808 \\
\hline & Five star & 55 & 35.46 & & & \\
\hline DTS9 & Four star & 16 & 37.84 & 410.5 & -0.42335 & 0.672039 \\
\hline DTS10 & Five star & 55 & 33.75 & & & \\
\hline DIS10 & Four star & 16 & 43.75 & 316 & -1.75745 & 0.078842 \\
\hline & Five star & 55 & 34.13 & & & \\
\hline DTSII & Four star & 16 & 42.44 & 337 & -1.47903 & 0.139131 \\
\hline DTS1? & Five star & 55 & 33.09 & & & \\
\hline D1S12 & Four star & 16 & 46.00 & 280 & -2.30607 & 0.021107 \\
\hline DTS13 & Five star & 55 & 34.45 & & & \\
\hline DTS13 & Four star & 16 & 41.31 & 355 & -1.21345 & 0.224958 \\
\hline & Five star & 55 & 35.26 & & & \\
\hline DTS14 & Four star & 16 & 38.53 & 399.5 & -0.62536 & 0.531737 \\
\hline DTS15 & Five star & 55 & 35.70 & & & \\
\hline DIS15 & Four star & 16 & 37.03 & 423.5 & -0.24278 & 0.808172 \\
\hline DTS16 & Five star & 55 & 36.22 & & & \\
\hline D1S16 & Four star & 16 & 35.25 & 428 & -0.17817 & 0.858591 \\
\hline & & & & Orga & onal Effectiv & ss Statements: \\
\hline OFC1 & Five star & 55 & 34.45 & & & \\
\hline UESI & Four star & 16 & 41.34 & 354.5 & -1.32374 & 0.185591 \\
\hline & Five star & 55 & 34.98 & & & \\
\hline OES2 & Four star & 16 & 39.50 & 384 & -0.83998 & 0.400922 \\
\hline OFC? & Five star & 55 & 34.70 & & & \\
\hline UESS & Four star & 16 & 40.47 & 368.5 & -1.09949 & 0.271557 \\
\hline OFCA & Five star & 55 & 34.56 & & & \\
\hline OES4 & Four star & 16 & 40.94 & 361 & -1.17993 & 0.238026 \\
\hline OFC5 & Five star & 55 & 35.26 & & & \\
\hline UESS & Four star & 16 & 38.53 & 399.5 & -0.58303 & 0.559875 \\
\hline OFS6 & Five star & 55 & 34.39 & & & \\
\hline UES6 & Four star & 16 & 41.53 & 351.5 & -1.2541 & 0.209804 \\
\hline OFC7 & Five star & 55 & 34.77 & & & \\
\hline UESI & Four star & 16 & 40.22 & 372.5 & -0.98549 & 0.324385 \\
\hline & Five star & 55 & 34.53 & & & \\
\hline OES8 & Four star & 16 & 41.06 & 359 & -1.17127 & 0.241492 \\
\hline OFCO & Five star & 55 & 35.46 & & & \\
\hline Uesy & Four star & 16 & 37.84 & 410.5 & -0.42683 & 0.669501 \\
\hline & Five star & 55 & 35.67 & & & \\
\hline OES10 & Four star & 16 & 37.13 & 422 & -0.26277 & 0.792727 \\
\hline
\end{tabular}


Reda M. A. Gadelrab

Appendix 2: Differences between Senior and Middle Managers' Scores - Mann Whitney U Test Statistics (a)

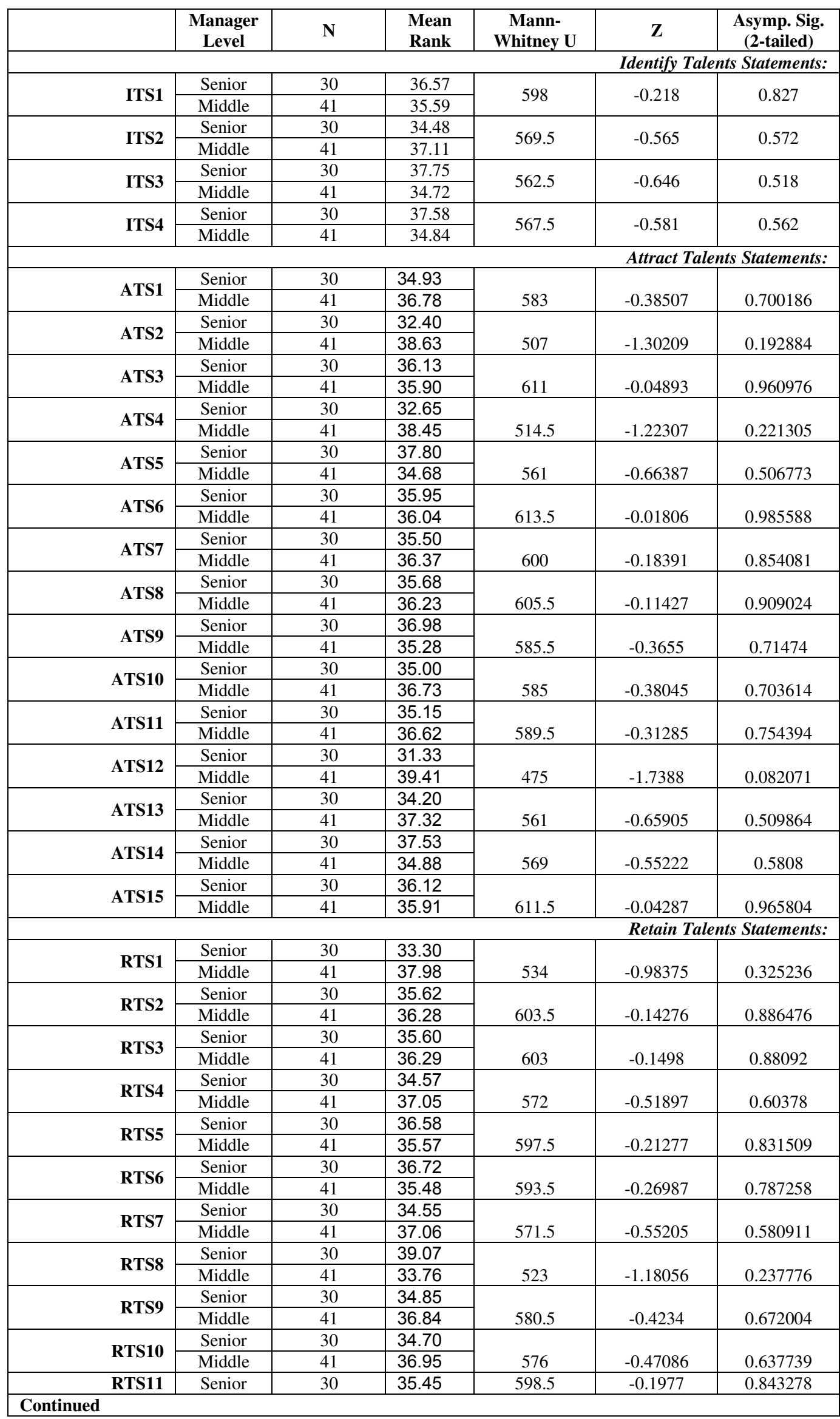


Exploring the Impact of Talent Management on the Organizational Effectiveness in the Egyptian Hospitality Industry

\begin{tabular}{|c|c|c|c|c|c|c|}
\hline & & & & & \multicolumn{2}{|c|}{ Appendix 2: Continued } \\
\hline & Middle & 41 & 36.40 & & & \\
\hline \multirow{2}{*}{ RTS12 } & Senior & 30 & 36.45 & \multirow[b]{2}{*}{601.5} & \multirow[b]{2}{*}{-0.16546} & \multirow[b]{2}{*}{0.868584} \\
\hline & Middle & 41 & 35.67 & & & \\
\hline \multirow{2}{*}{ RTS13 } & Senior & 30 & 34.18 & \multirow[b]{2}{*}{560.5} & \multirow[b]{2}{*}{-0.66112} & \multirow[b]{2}{*}{0.508536} \\
\hline & Middle & 41 & 37.33 & & & \\
\hline \multirow{2}{*}{ RTS14 } & Senior & 30 & 37.27 & \multirow[b]{2}{*}{577} & \multirow[b]{2}{*}{-0.45982} & \multirow[b]{2}{*}{0.645647} \\
\hline & Middle & 41 & 35.07 & & & \\
\hline \multirow{2}{*}{ RTS15 } & Senior & 30 & 34.23 & & & \\
\hline & Middle & 41 & 37.29 & 562 & -0.641 & 0.521522 \\
\hline & & & & & Develop $T$ & Statements \\
\hline & Senior & 30 & 34.75 & & & \\
\hline DIS1 & Middle & 41 & 36.91 & 577.5 & -0.46641 & 0.64092 \\
\hline & Senior & 30 & 37.40 & & & \\
\hline DIS2 & Middle & 41 & 34.98 & 573 & -0.55338 & 0.580006 \\
\hline & Senior & 30 & 34.67 & & & \\
\hline DIS3 & Middle & 41 & 36.98 & 575 & -0.502 & 0.615671 \\
\hline DTS4 & Senior & 30 & 36.00 & & & \\
\hline 0154 & Middle & 41 & 36.00 & 615 & 0 & 1 \\
\hline & Senior & 30 & 32.70 & & & \\
\hline DISS & Middle & 41 & 38.41 & 516 & -1.22681 & 0.219896 \\
\hline DTS6 & Senior & 30 & 33.43 & & & \\
\hline DIS6 & Middle & 41 & 37.88 & 538 & -0.9282 & 0.353306 \\
\hline & Senior & 30 & 33.18 & & & \\
\hline DIS/ & Middle & 41 & 38.06 & 530.5 & -1.00608 & 0.314376 \\
\hline DTS8 & Senior & 30 & 35.62 & & & \\
\hline OTSO & Middle & 41 & 36.28 & 603.5 & -0.14072 & 0.888089 \\
\hline & Senior & 30 & 33.75 & & & \\
\hline DIS9 & Middle & 41 & 37.65 & 547.5 & -0.81935 & 0.412584 \\
\hline & Senior & 30 & 35.83 & & & \\
\hline DISIO & Middle & 41 & 36.12 & 610 & -0.05994 & 0.952203 \\
\hline & Senior & 30 & 36.55 & & & \\
\hline DISI & Middle & 41 & 35.60 & 598.5 & -0.20041 & 0.841162 \\
\hline & Senior & 30 & 34.00 & & & \\
\hline 01512 & Middle & 41 & 37.46 & 555 & -0.73146 & 0.464497 \\
\hline & Senior & 30 & 35.30 & & & \\
\hline DIS13 & Middle & 41 & 36.51 & 594 & -0.25358 & 0.799822 \\
\hline & Senior & 30 & 34.17 & & & \\
\hline DIS14 & Middle & 41 & 37.34 & 560 & -0.71833 & 0.472554 \\
\hline & Senior & 30 & 35.62 & & & \\
\hline D1S15 & Middle & 41 & 36.28 & 603.5 & -0.14313 & 0.886189 \\
\hline DTS16 & Senior & 30 & 34.65 & & & \\
\hline D1S10 & Middle & 41 & 36.99 & 574.5 & -0.50862 & 0.611021 \\
\hline & & & & Orga & nal Effectiv & Statements \\
\hline OFS1 & Senior & 30 & 33.85 & & & \\
\hline UEST & Middle & 41 & 37.57 & 550.5 & -0.84466 & 0.398299 \\
\hline OFS? & Senior & 30 & 34.47 & & & \\
\hline OES2 & Middle & 41 & 37.12 & 569 & -0.58361 & 0.559481 \\
\hline OFS3 & Senior & 30 & 39.57 & & & \\
\hline UESS & Middle & 41 & 33.39 & 508 & -1.39173 & 0.164003 \\
\hline & Senior & 30 & 36.42 & & & \\
\hline OES4 & Middle & 41 & 35.70 & 602.5 & -0.15792 & 0.874522 \\
\hline OFS5 & Senior & 30 & 36.95 & & & \\
\hline UESS & Middle & 41 & 35.30 & 586.5 & -0.34703 & 0.728569 \\
\hline & Senior & 30 & 33.68 & & & \\
\hline OES6 & Middle & 41 & 37.70 & 545.5 & -0.83304 & 0.404824 \\
\hline OFS7 & Senior & 30 & 32.82 & & & \\
\hline OESI & Middle & 41 & 38.33 & 519.5 & -1.17934 & 0.238263 \\
\hline OFSQ & Senior & 30 & 35.72 & & & \\
\hline UESO & Middle & 41 & 36.21 & 606.5 & -0.10396 & 0.917199 \\
\hline OFSO & Senior & 30 & 36.77 & & & \\
\hline UESY & Middle & 41 & 35.44 & 592 & -0.28148 & 0.77834 \\
\hline OFS10 & Senior & 30 & 33.75 & & & \\
\hline UESTO & Middle & 41 & 37.65 & 547.5 & -0.83349 & 0.404571 \\
\hline
\end{tabular}




\section{إيضاح أثر إدارة المواهب في الفعالية التنظيمية في صناعة الضيافة \\ رضا محمد عبد الحفيظ جادالرب الرب في في \\ كلية السياحة والفنادق -جامعة حلوان}

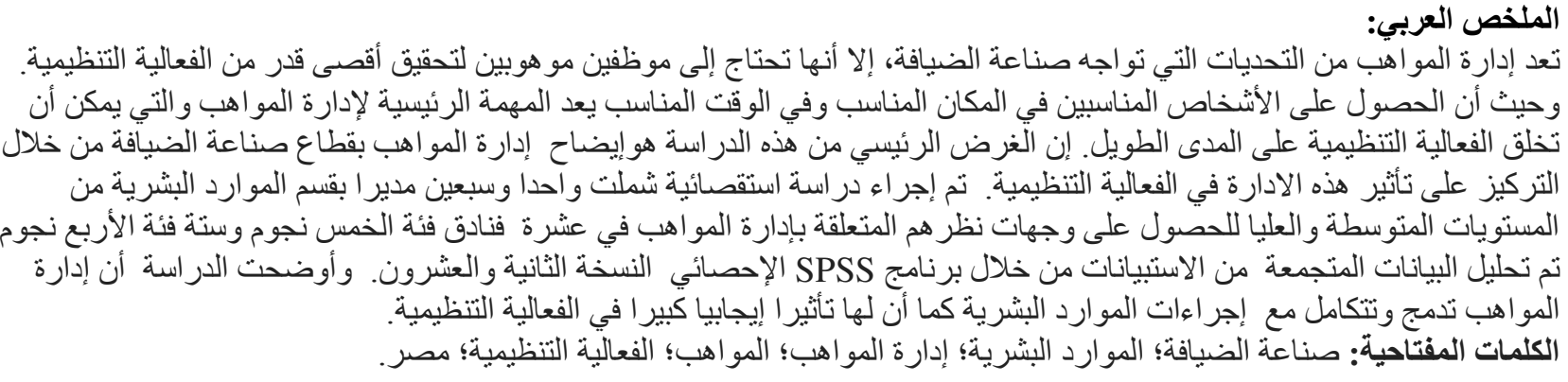

